\title{
The Points of School Directors on Peer Observation as a New Professional Development and Supervision Model for Teachers in Turkey
}

\author{
Ahmet Bozak ${ }^{1, *}$ \\ ${ }^{1}$ School of Education, Hatay Mustafa Kemal University, Hatay, Turkey \\ *Correspondence: School of Education, Hatay Mustafa Kemal University, Serinyol, Hatay, Turkey. Tel: \\ 90-326-245-6000. E-mail: abozok77@gmail.com
}

Received: July 29, 2018

Accepted: September 5, $2018 \quad$ Online Published: October 1, 2018

doi:10.5430/wje.v8n5p75

URL: https://doi.org/10.5430/wje.v8n5p75

\begin{abstract}
The aim of the study is to determine the views of school managers' towards peer observation as an alternative teacher professional development and complementary supervision model. The study was conducted through a mix research model which combines quantitative and qualitative methods based on convergent parallel design. 121 school managers voluntarily joined the study at the end of the conference to which the researcher was invited as guest speaker. The results of the study in quantitative dimension indicated that peer observation was considered by school managers as an alternative teacher development model to promote cooperation among teachers; self-awareness of teachers; motivation; solving their problems cooperatively; learning new methods. The qualitative results also indicated that majority of the participants were in favour of peer observation as an alternative personal development method for teachers; the participants recommended that it should be carried via volunteers between different schools; just friendly and positive feedback should be given to the teacher who teaches the same subject; should be carried in a friendly school climate where there is no rivalry among teachers. On the other hand, some participant expressed their negative concerns as there wouldn't be enough teachers and time; the teacher would hesitate to be observed because of political and professional rivalries, lack of confidence and trust among teachers.
\end{abstract}

Keywords: peer observation, practicability, teachers, school managers

\section{Introduction}

Peer supervision and the peer observation method within the supervision process towards teachers has become widespread and attracted attention of many researchers for the last 20 years (Bennett and Barp, 2008; Bowers, 1999; Cosh, 1999; Rhodes and Beneicke, 2002; Shortland, 2004).

Peer observation of teaching can be defined as:

Collaborative, developmental activity in which professionals offer mutual support by observing each other teach; explaining and discussing what was observed; sharing ideas about teaching; gathering student feedback on teaching effectiveness; reflecting on understandings, feelings, actions and feedback and trying out new ideas (Bell, 2005).

Peer observation is considered to have multiple functions and benefits for teachers, for example, it can be used for continuing professional development (CPD) purposes via observation and learning; for sharing teachers' knowledge and experiences with each other; for improving a common understanding towards the implementation of educational programs; for developing a common educational plan via peer collaboration; for improving teachers' self-evaluation and self-esteem competences (Shortland, 2004; Joyce and Showers, 2002; Martin and Double, 1998).

There are some crucial points for peer observation's being efficient, first, voluntary participation and mutual trust between the peers. Peer's being volunteer, as well as trust between two colleagues, has key role in order to get the expected results in the application process (Hanna, 1988; Sullivan and Glanz, 2000). Second, the whole staff who is going to join the observation process should be trained to be a good observer (Hammersley-Fletcher and Orsmond, 2005). 
Siddiqui and et. al (2007) also argue that there are 12 important tips for peer observation, these are (i) to choose the observers in a careful way; (ii) to set aside time for the observation process; (iii) to clarify what are expected from observers; (iv) to be informed about the course and lesson that is going to be observed; (v) to choose the suitable instruments for observation; (vi) to inform the students beforehand about the observer and what s/he is going to do in the lesson; (vii) to be objective during the observation; (viii) not to compare with or urge one's own teaching style; (ix) not to intervene in teaching activities during the lesson; $(x)$ to feedback carefully and politely after the observation; (xi) to respect confidentiality, to follow the professional and ethical standards; (xii) to regard observation as a learning experience and opportunity.

Peer observation is a cyclical process which includes, in general, a pre-observation meeting, classroom observation and post-observation meeting (Bell, 2002; Bowers, 1999). Pre-observation meeting guides to planning and what is going to be done in the observation process. Classroom observation should be in accordance with how it was planned, feedbacks and observation process should be evaluated by peers (British Council, 2010).

Experienced teachers may use peer observation process to confirm their classroom instruction activities or dispel concern about their instruction methodology, veteran teachers, who know well that even the best instruction can be improved, may benefit from such an observation process carried by collaboration and reflection (Bowers, 1999). Peer observation is considered to be a model that makes contribution to improvements of teaching practices, development of confidence to teach, transformation of educational perspectives between teachers; dissemination of good teaching practices among teachers; improvement of instruction by creating a positive learning environment; increase collaboration among teachers and promote ongoing professional development of teachers (Bell, 2005; Bell and Mladenovic, 2008; Bowers, 1999; Hammersley-Fletcher and Orsmond, 2005; Hanna, 1988).

Beside its benefits and positive instructional contributions to professional development of teachers, peer observation method is likely to have some negative points itself such as teachers' being reluctant to be observed by a colleague in their own classes and their being sensitive to receive criticism about their teaching applications, such challenges in peer observation process should also be met by the implementers. The close partnership between peers is crucial, as peer observation will mostly be ineffective if collaboration and trust between peers is weak. Peer teachers' individual and professional qualification towards observation, their trust and respect each other are also important for peer observation process's being successful (Rhodes and Beneicke, 2002). Most of these handicaps are said to have originated from teachers' being inadequate for making observation and giving feedback, peers' not being voluntarily chosen and school culture's not being suitable for peer observation (Bowers 1999); peer observation can also be negatively affected by peer's being delicate to criticism and feedback, peer's having difficulties to review their own colleagues, peer's being reluctant to leave their class because of their work load (Straughter, 2001), teacher's not having enough time for observation, teachers' having different educational and instructional backgrounds and expectations as well as different supervisory perspectives (Morton, 2004), peers' lack of pedagogical competences and not focusing on classroom activities (Peel, 2005).

Although there might be some obstacles and negative points in the application process, peer observation is still worth implementing towards the professional development and supervision of teachers when its positive contributions and benefits were considered. Consequently, the views of school managers about peer observation are thought to make a contribution to the improvement of a new alternative supervision perspective that will mutually complement formal supervision process towards school teachers.

The history of supervision in Turkey goes back to 1879 , since then, there has always been an inspectorate unit in the ministry of education towards the supervision of teachers and schools, and also the inspection system itself has undergone a radical change since the beginning of 20 th century (Su, 1974; Buluç, 1997; Usta, 2017). Inspection and supervision activities were carried by professional supervisors working in districts and general inspectorates in Turkey. A number of structural changes towards Turkish supervision system have been put into practice in the last decade, classroom visits and teacher interviews by supervisors, which is considered as a critical part of supervision, was dismissed (Bozak, 2017), instead, school managers were tasked with classroom visits and supervision towards teachers expecting that the school manager will have longer time and more chance to observe classes, as a result, they will be able to make better contribution to professional development of teachers.

While supervision by school managers was praised in many studies, in some studies supervision carried by school managers were also found not to come up with desired results as teachers have some negative concerns. Some of those studies disclosed that principals could not perform their supervision duty of education and teaching sufficiently (Gündüz, 2017); teachers have anxiety for misuse of supervision power by school managers and this might cause conflicts among teachers and school management (Tonbul and Baysülen, 2017); teachers expected their performance 
to be evaluated in a longer process rather than short classroom visits by managers (Yıldız, Akbaşlı and Üredi, 2015); teachers over 20 years and more seniority found the supervision carried by school managers inactive and didn't welcome theirs instructional expectations (Özmen and Batmaz, 2006); school managers could be nonobjective to evaluate their true performances because of having different political views (Ergen and Eşiyok, 2017; Aslanargun and Göksoy, 2013).

Although peer observation is personally and unofficially practiced by a limited number of teachers in Turkish education system, it is not yet a well-known professional development model for teachers as well as the number of the studies on peer observation is limited comparison to other countries. One of the main objectives of supervision towards teachers is to improve teachers' professional development, so peer observation can function as an alternative and complementary supervision activity that can be easily combined to current supervision system if it is profoundly presented to school managers and teachers in Turkish education system.

In year 2017, a number of CPD conferences were organized towards school managers by Local Educational Directorate of Hatay in order to introduce new methods and trends in education. The researcher was invited as guest speaker to these conferences organised in İskenderun and Antakya districts as he has a number of academic studies on peer observation. The researcher, as a guest speaker, explained what the peer observation was and how it was applied as a professional development method towards teachers at school, critical points during the application as well as positive and negative effects of the method within an hour presentation.

The main objective of this study is to display the views of school managers towards peer observation by introducing the peer observation as an alternative and complementary professional development and supervision model for teachers. Peer observation is not systematically and officially applied in Turkish supervision system, therefore, defining the school managers' views on practicability and effectiveness of peer observation is thought to lead this method's being applied as an alternative complementary method which will complete the present Turkish supervision system.

More specifically, this research aims to answer two questions. First, the study seeks to disclose the views of school managers about practicability and effectiveness of peer observation as an alternative complementary method. Second, to reveal the views of school managers about weak and strong points of peer observation as an alternative professional development and supervision method towards teachers.

\section{Method}

Research design, study groups, data collection tool and data analysis are explained under this heading.

\subsection{Research Design}

The study was conducted through a mix research model which combines quantitative and qualitative research methods based on a convergent parallel design (Creswell \& Garrett, 2008; Creswell \& Plano Clark, 2014). While quantitative and qualitative data are simultaneously collected but separately analysed and the results of both methods are harmonically interpreted (Creswell \& Plano Clark, 2014).

\subsection{Study Group}

At the end of these conferences, the researcher, as a guest speaker, answered the further questions of the school managers, and also, a group discussion was made about the method for another 40 minutes. Following the questions and answers, the school managers were asked that they could join the survey, it was not an obligation but volunteering, in any way their views were precious for the research and their personal views and information will just be used in this research and won't be displayed or shared for other purposes. At the end of these conferences, 121 managers voluntarily joined the study and stated their free views towards peer observation method. On the other hand, the phenomenological interviewing open-ended question was answered by only 45 participants. 
Table 1. Distribution of the Participants According to School Type and Seniority

\begin{tabular}{|c|c|c|c|}
\hline & & Participants & Percentage (\%) \\
\hline \multirow{6}{*}{ Type of the School } & Pre-school & 2 & 1,7 \\
\hline & Primary & 38 & 31,4 \\
\hline & Secondary & 17 & 14,0 \\
\hline & $\begin{array}{r}\text { Primary + secondary } \\
\text { (United Elemetary) }\end{array}$ & 9 & 7,4 \\
\hline & High School & 22 & 18,2 \\
\hline & Notspecified & 33 & 27,3 \\
\hline \multirow{5}{*}{ Seniority } & 1-10 Years & 7 & 5,8 \\
\hline & 11-20 Years & 40 & 33,1 \\
\hline & 21 Years and more. & 53 & 43,8 \\
\hline & Notspecified & 21 & 17,4 \\
\hline & Total & 121 & $\% 100$ \\
\hline
\end{tabular}

\subsection{Data Collection Tool}

Quantitative data were collected by means of a survey, which was adapted from a survey which was previously developed by the researcher towards defining teachers' views on peer observation method (Bozak, 2014), Following the data items of previous survey being restated by the researcher towards school managers, the new data items were reviewed by two assistant professors working at the department of educational sciences as well as by an educational general supervisor who has Ph.D. in educational sciences. The last articulation of the items was formed by a group focus on the participation of two assistant professors working at the department of educational sciences.

The survey was formed by three sections, the first section is about demographic information of the participants such as seniority and type of the school they work at, the second section was formed by 26 data items stating benefits and negative sides of peer observations. And the last section was formed by a phenomenological interviewing open-ended question to collect qualitative data.

26 data items in quantitative dimension of the survey were formed by finding and results on peer observation and peer coaching literature, and were designed according to five-level Likert item, level of agreement/disagreement was ranged by (1) strongly disagree; (2) disagree; (3) neither agree nor disagree; (4) agree and (5) strongly agree. The first 10 data items (1-10) were formed by positive statements related to peer observation and coaching while the next 10 data item (11-20) was formed by negative statements and disadvantages of peer observation. Finally, the last six data items (21-26) were formed by statements comparing peer observation with the current supervision model carried by school managers.

The last section, qualitative dimension, was formed by a phenomenological interviewing open-ended question, the participants were asked to explain their general opinions about peer observation method.

\subsection{Data Analysis}

The relevant data in the quantitative dimension of the study was analysed by mean of the Statistical Package for the Social Sciences (SPSS), as common in a survey rather than a scale, the means and percentages of each item were evaluated and interpreted by tables. No other analysis was done except for means and percentages of each item in the survey.

The relevant data in qualitative dimension, a phenomenological interviewing method, which is considered to be a type of qualitative research, was used. In order to lessen the subjectiveness that might stem from the participants, similar questions were asked orderly asked the participants in a written way. And the method is also regarded to have some advantages in terms of analysing and comparing quantitative data (Karasar, 2005; Punch, 2005, Yıldırım and Şimşek, 2006). The particpants were asked to write their general opinions about peer observation method in an open-ended question. Similar opinions and statements about peer observation were gathered into themes and also supported by frequency distribution. The views of participants, considered to be important or authentic for the study, were also quoted via direct citations. 
The criteria of "Trustworthiness" are more commonly used in qualitative method apart from the traditional reliability-validity approach in quantitative studies. Trustworthiness is the indications of a researcher's credibility and dependability (Daymon and Holloway, 2003; Shenton, 2004; Yıldırım, 2010). In qualitative research, it is important that the participants should give more detailed and sincere answers to the questions, so orderly written phenomenological question questions were posed the participants and they were asked to write their free opinions about the method, their concern as well as their positive views.

According to Guba (1981), qualitative method has four main features, these are credibility, transferability, dependability and conformability. (cited in Shenton, 2004; Uzuner 2005). In order to fulfill credibility, dependability and conformability in the study, quantitative and qualitative research methods were used together to get methodological diversity, random sampling was used, participants were voluntarily chosen, the data collection tool was developed and revised with consulting to peer experts in educational fields and the literature in accordance with the scientific references, the methodology and main objectives of the study were explained in clear details. Although transferability of the results in the qualitative method is disputable, the study was supported by quantitative dimension to fulfill transferability. One of the other ways of transferability is to give detailed information about the research process such as the number and identity of the participants, their fields, how the data was collected etc. All these criteria above were fulfilled, ethical standards were considered, and the research process was honestly committed to paper by the researcher in the study.

\section{Results}

The findings of the study in quantitative and qualitative dimensions were explained below.

\subsection{The Findings Related to the Quantitative Dimension of the Study}

(1) The level of participation of the school managers at "agree and strongly agree" levels related to the positive statement data items that peer observation is likely to "promote cooperation among teachers; promote self-awareness of teachers by teachers' self-evaluating their own teaching methods and technics; promote teachers' motivation as they would see their positive and strong sides; make contribution to solving their problems cooperatively; be a new professional development model for teachers; promote performance of the school and led them learn new methods and technics by giving feedback each-others" was over $75 \%$ and relatively higher than the participation levels of the other data items and it relatively indicates that the school managers support those positive views about peer observation. Related percentage and frequency ratio of these data items are shown in table 2 below.

Table 2. Table Indicating Percentage and frequency Ratio of the Participants Related to Positive Data Items

\begin{tabular}{|c|c|c|c|c|c|c|c|c|c|c|}
\hline & & & & 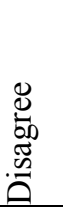 & $\begin{array}{l}\bar{\Phi} \\
: \overline{0} \\
\bar{Z}\end{array}$ & 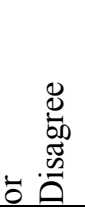 & & $\frac{8}{D_{0}}$ & & 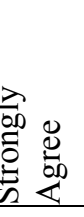 \\
\hline & $\mathbf{f}$ & $\%$ & f & $\%$ & f & $\%$ & f & $\%$ & f & $\%$ \\
\hline Promoting cooperation among teachers & 1 & 0.8 & 5 & 4.1 & 14 & 11.6 & 55 & 45.5 & 46 & 38.0 \\
\hline $\begin{array}{l}\text { Promoting self-awareness of teachers by teachers' self-evaluating } \\
\text { their own teaching methods and technics; }\end{array}$ & 0 & & 2 & 1,7 & 16 & 13.2 & 65 & 53.7 & 38 & 31.4 \\
\hline $\begin{array}{l}\text { Promoting teachers' motivation as they would see their positive and } \\
\text { strong sides }\end{array}$ & 0 & 0 & 4 & 3.3 & 25 & 20.7 & 54 & 44,6 & 38 & 31.4 \\
\hline Making a contribution to solving their problems cooperatively & 0 & 0 & 2 & 1,7 & 13 & 10.7 & 63 & 52.1 & 43 & 35.5 \\
\hline Being a new professional development model for teachers & 1 & 0.8 & 3 & 2.5 & 24 & 19.8 & 56 & 46.3 & 37 & 30.6 \\
\hline Promoting performance of the school. & 0 & 0 & 1 & 0.8 & 22 & 18.2 & 49 & 40.5 & 49 & 40.5 \\
\hline Learning new methods and technics by giving feedback each-others & 0 & 0 & 6 & 5.0 & 18 & 14.9 & 59 & 48.8 & 38 & 31.4 \\
\hline
\end{tabular}


(2) The levels of participation of the school managers related to the data items negatively stating that "there is no mutual trust atmosphere in our school to be able to apply such a model; this model is likely to be unsuccessful as there isn't a positive culture of constructive criticism among teachers; as it is a time-consuming process, it would be difficult to apply" were not coherent, distribution of related percentage and frequency ratio of these data items are shown below in table 3 .

Table 3. Table Indicating Percentage and Frequency Ratio of the Participants Related to Negative Data Items

\begin{tabular}{l}
\hline \\
\hline
\end{tabular}

(3) The level of participation of the school managers related to the data items negatively stating that "teachers dislike to be observed in their classes, as they will regard their classes as their own private ground (41,4\%); teachers' being sensitive and delicate to criticism will be an obstacle for implementing this method (47,9\%); it will be difficult for teachers to be able to make an objective observation (45,5\%)" was over $40 \%$ and relatively higher than the participation levels of the other negative statement data items and it indicates that the school managers feel some irresolution about peer observation as they relatively support those negative views at "agree and strongly agree" levels. Related percentage and frequency ratio of these data items are shown down in table 4 .

Table 4. Table Indicating Percentage and Frequency Ratio of the Participants Related to Negative Data Items

\begin{tabular}{|c|c|c|c|c|c|c|c|c|c|c|}
\hline & & 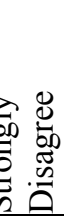 & & 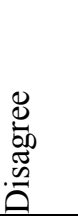 & 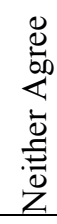 & 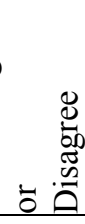 & & 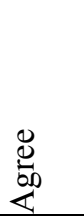 & & : \\
\hline & f & $\%$ & f & $\%$ & $\mathbf{f}$ & f & $\%$ & $\mathbf{f}$ & $\%$ & $\mathbf{f}$ \\
\hline $\begin{array}{l}\text { Teachers will dislike to be observed in their classes, as they regard } \\
\text { their classes as their own private ground }\end{array}$ & 3 & 2,5 & 19 & 15,7 & 49 & 40,5 & 36 & 29,8 & 14 & 11,6 \\
\hline $\begin{array}{l}\text { Teachers' being sensitive and delicate to criticism will be an obstacle } \\
\text { for implementing this method. }\end{array}$ & 2 & 1,9 & 16 & 13,2 & 45 & 37,2 & 46 & 38 & 12 & 9,9 \\
\hline $\begin{array}{l}\text { It will be difficult for teachers to be able to make an objective } \\
\text { observation. }\end{array}$ & 3 & 2,5 & 18 & 14,9 & 45 & 37,2 & 45 & 37,2 & 10 & 8,3 \\
\hline
\end{tabular}

(4) The level of participation of the school managers at "agree and strongly agree" levels stating that "peer observation as a supervision method will be more didactic (74,4\%); will make more contribution to teachers' professional development comparison to the supervision that has been carried by school managers for teachers $(76,8 \%)$ " was relatively higher than the participation levels of the other comparative statement data items and it indicates that the school managers support those comparative views that peer observation as a supervision method will be more didactic; will make more contribution to teachers' professional development comparison to the supervision that has been carried by school managers for teachers. Related percentage and frequency ratio of these data items are shown down in table 5. 
Table 5. Table Indicating Percentage and Frequency Ratio of the Participants Related to Negative Data Items

\begin{tabular}{|c|c|c|c|c|c|c|c|c|c|c|}
\hline & \multicolumn{2}{|c|}{ 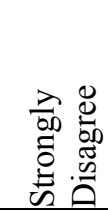 } & \multicolumn{2}{|c|}{ 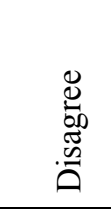 } & \multicolumn{2}{|c|}{ 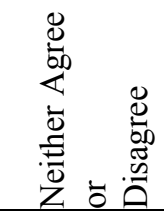 } & \multicolumn{2}{|r|}{$\underset{\mathscr{0}}{\stackrel{D}{L}}$} & \multicolumn{2}{|c|}{ 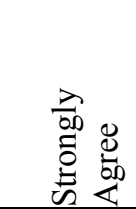 } \\
\hline & f & $\%$ & f & $\%$ & f & f & $\%$ & f & $\%$ & f \\
\hline $\begin{array}{l}\text { Comparison to the supervision that has been carried by } \\
\text { school managers for teachers, peer observation as a } \\
\text { supervision method will be more didactic. }\end{array}$ & 1 & 0.8 & 5 & 4.1 & 25 & 20.7 & 53 & 43.8 & 37 & 30.6 \\
\hline $\begin{array}{l}\text { Comparison to the supervision that has been carried by } \\
\text { school managers for teachers, it will make more contribution } \\
\text { to teachers' professional development. }\end{array}$ & 1 & 0.8 & 2 & 1.7 & 25 & 20.7 & 69 & 57 & 24 & 19.8 \\
\hline
\end{tabular}

\subsection{The Findings Related to the Qualitative Dimension of the Study}

(1) An important number of the participants $(68 \% ; n=31)$ opined in favour of peer observation and they clearly stated that the peer observation method was practicable for teachers as an alternative teacher development and complementary supervision model. The following quotations also support this clearly:

"It's a practicable method by means of which you could get positive outcomes" (M-24);

"Practicable, especially it will improve the cooperation among the teachers who teach the same subject" (M-41)

However some of these participants state that the method is practicable itself but for this method to be successful, it is necessary that it should be applied by volunteer teachers (M-1; M-21); teachers should be guided by other teachers working at different schools rather than the teachers working at the same school (M-3); it should be applied to different schools, not among the same school staff (M-4); positive feedbacks should be given within mutual understanding and respect without offending each other (M-8; M-9); it should be applied to same subject teachers (M-18); it should be applied in a warm and truthful atmosphere, there shouldn't be rivalry and conflicts among teachers (M-22); there should be favorable and effective communication between teachers (M-23); it should be applied honestly, truthfully and objectively by peer teachers (M-25); it should be applied to teachers who are open for improvement and professional development (M-34); it should be organized, focused and emphasized by school management (M-38; M-39).

Some of the pro-arguments and counter arguments of the participants are seen in following quotations:

"It will be useful if it is applied by volunteer teachers" (M-1);

"The necessary education and training for peer observation should be given and guided by teachers from other schools, rather than the teachers working at the same school, otherwise it would be regarded as a fatigue duty by teachers" (M-3);

"If it were put into practice, it would be a perfect method and it would definitely increase the success at schools" (M-5);

"It could be useful if feedbacks are given in a way that will make contribution to teacher's professional development within mutual understanding and respect without being offending each other" (M-8);

"If only people could positively criticize each other within mutual understanding and respect, if people can do this, I believe that this method will be useful" (M-9);

"It will be useful for teachers when it is applied by the same subject teachers, otherwise, different subject teachers" observing each other will not be more than an observation of class management" (M-18);

"I believe that it will be useful if teachers become volunteer for observing their colleagues" (M-21);

"It will be difficult to be able to apply such a method in schools, if there is rivalry and conflicts among teachers. I already practiced this method in my previous schools with my close friends at school" (M-21);

"The success of such a method depend on the climate among teachers, if there is not a warm and truthful atmosphere among teacher, it might increase the problems, even so, I believe that it will be useful, if it could be truly applied" (M-23);

"if it could be honestly, truthfully and objectively applied, it would be successful" (M-25);

"If it is applied onto teachers who are open for improvement and professional development, it will be successful, but still, most of the teachers will shut down themselves for such a method" (M-34); 
"it will be so useful, if it is organized, focused and emphasized by school management. Feedbacks related to peer observation should be regularly reviewed by school management" (M-38);

"The application of this method mainly depend on school managers, if we can truly understand this method and truly explain to our teachers, I believe that this method can be applicable for schools" (M-39);

(2) Some of the participants $(31,2 \% ; n=14)$ expressed their negative points of view about peer observation as there would not be enough number of teachers from each subject in all schools especially at countryside (M-7); as teachers would be refrained from being blamed as a "ineligible teacher" if their insufficiency in the class were observed and noticed (M-17); as teachers would not have enough time because of their full lesson week schedule (M-19); as teachers would act in a different way and would not introduce their real teaching performance (M-26); as organizational culture among teachers would make this method's being applied difficult (M-28); as teachers would hesitate to be observed in the classes because of their insufficiency (M-35); as there would be political and professional rivalries (M-36) and lack of confidence and trust among teachers (M-37).

Some of the negative counter arguments of the participants are seen in following quotations:

"It will not be possible to apply especially in the schools at countryside where there are not enough number of teachers from each subject” (M-5);

"I believe that we are not matured enough to apply such a method in our schools" (M-10);

"Teachers might be refrained from being blamed as a "ineligible teacher" if their insufficiency in the class were observed and noticed. Unfortunately, such arguments in big school are quite common, moreover, some teachers known as successful might be unopened to learning a new method" (M-17);

"There might be a problem of not having enough time for application of the method" (M-19);

"Teachers might display a high teaching performance just for the sake of the lesson in which he is observed, that is to say, teachers might introduce himself to the person who comes to observe him much better than he actually is" (M-26);

"Teachers don't wish to be observed in the classes because of their insufficiency" (M-35);

"First of all, teachers' mind and mentalities ought to be chanced before applying such a method, political and professional rivalries in the minds should be wiped away" (M-36);

"This may be applied when there is confidence and trust among people, but it seems difficult to be able to apply such a method in current conditions because today's human beings are so harsh" (M-37);

\section{Discussion}

Participants mostly agreed that peer observation will promote cooperation among teachers; promote self-awareness of teachers by self-evaluating their own teaching methods and techniques; promote teachers' motivation as they would see their positive and strong sides; make contribution to solving their problems cooperatively; be a new professional development model for teachers; promote performance of the school and lead them to learn new methods and techniques by giving feedback to each other. This indicated that peer observation was generally welcomed by school managers and they intend to apply it as an alternative teacher development model when its positive benefits are accounted for school success and teachers personal improvements.

This result is consistent with the results of some previous studies on peer observation. In previous studies on peer coaching and peer supervision it was disclosed that it was an effective method for improvement of teaching capabilities (Hanna, 1988); a method that allow teachers share instructional methods and techniques by giving positive feedbacks and observing each other in the class (Potter, 1991); a method which leads to synergy and togetherness among the participants (Bowers, 1999; Rouser, 2009); a method that improves the individual teaching competence and form a more cooperative and positive learning environment (Nelson, 2000; Blanco, 2007; Clark, 2017); a method in which teachers support and trust more each other (Straughter, 2001); a method that increases helping each other, cooperation and learning from each other (Bourne-Hayes, 2010; Hirsch, 2011); a method that improves the positive communication among teachers and improve teachers' problem solving capabilities (Doyle, 2012); a method that is likely to improve professional self-awareness and self-reliance (Cribbs, 2009); a method that makes contribution to success of instruction and management (Shook, 2011) a method that facilitates faculty professional growth and development through systematic and constructive ways (Crabtree and et. al, 2016).

Although peer observation was mostly approved by the school managers and they intend to apply it as an alternative teacher development and supervision model, some participant's views disclosed that it still had some shortcomings 
which are critical for the success of the process. Some participants expressed that it is really important for the success of such a model's being implemented by volunteer teachers; teachers' being guided by other teachers from different schools; being positively reviewed via mutual understanding and respect as well as not offending each other; teachers' being observed by the same subject professionals; having a warm, truthful, favorable and effective communication atmosphere during the implementation which is rather away from rivalry and conflicts; teachers' being honest, truthful and objective while observing the other teachers; the method's being applied by teachers who are open for improvement and professional development; teachers' having support from school management during the peer observation process.

As it was also uttered by some school managers in this study above, Byrne (1983); Hanna (1988); Sullivan and Glanz (2000) also emphasized that peer observation should be implemented by volunteers, and it is an important aspect that is likely to increase the success of peer observation. Some of the school managers in the study believe that peer observation should be guided by outsider teachers from different schools. Consistent with the views of participant school managers, in a study by Walker and Forbes (2017), it is argued that working with an external colleague "outside the family" in a peer observation process can introduce for peers a broader and more diverse perspective than the organization's internal peer exchange.

Other concerns of participants that peer observation should be carried in a warm, truthful, favourable and effective communication atmosphere which is rather away from rivalry and conflicts were also highlighted by previous researchers. Salvador (2012), in his study, argue that mutual trust among the peers is a critical aspect of a successful peer observation process; similarly, Hornby's (2008) study revealed that peers who are going to join the process should have certain qualification for observation; Younghans (2010) states that inattentively chosen peers can spoil the observation process rather than making contributions.

Unlike positive perspective for peer observation some participant clearly stated their negative points of view, the method will be ineffective because of not having enough number of teachers from each subject; not having enough time; teachers' being refrained from labeling as an "ineligible teacher" as their personal insufficiency in the class would be observed and noticed; teachers' not introducing their real teaching performance; having negative organizational culture; political and professional rivalries at schools; lack of confidence and trust among teachers.

The result in quantitative dimension were also likely to support those concerns because the level of participation of the school managers related to the data items negatively stating that "teachers dislike to be observed in their classes, as they will regard their classes as their own private ground (41,4\%); teachers' being sensitive and delicate to criticism will be an obstacle for implementing this method (47,9\%); it will be difficult for teachers to be able to make an objective observation (45,5\%)" was over $40 \%$ and relatively higher than the participation levels of the other negative statement data items and it indicates that the school managers feel some irresolution about peer observation as they relatively support those negative views at "agree and strongly agree" levels.

Consistent with this result, in some previous studies it was found that teachers' not having enough time for application could be an obstacle while conducting peer observations, if enough time was not given or teachers' schedule was not organized in a good way to complete observations (Hammersly-Fletcher \& Orsmond, 2005; Clark, 2017).

School culture is said to be an important factor for a successful observation process, Bowers (1999) argue that peer observation would totally remain unsuccessful since the beginning if the school culture was not supportive of collaboration. However, peers' being voluntarily chosen may help to build up a supportive school culture and a successful peer observation process.

\section{Conclusion}

When the quantitative and qualitative findings of the study were reviewed together, the following results were found in this study.

(1) Peer observation, as an alternative teacher professional development model, is practicable and effective as it is likely to promote cooperation among teachers; promote self-awareness of teachers by teachers' self-evaluating their own teaching methods and techniques; promote teachers' motivation as they would see their positive and strong sides; make contribution to solving their problems cooperatively; be a new professional development model for teachers; promote performance of the school and lead them to learn new methods and techniques by giving feedback to each other. This indicated that peer observation as an alternative teacher development model was generally welcomed by school managers when its positive benefits are counted for school success and teachers personal 
improvements.

(2) Although peer observation has many positive sides that make contributions to teacher and learning environment, it has also some shortcomings which are critical to the success of the process. It is really important for the success of peer observation's being implemented by volunteer teachers; teachers' being guided by other teachers from different schools; being positively reviewed via mutual understanding and respect as well as not offending each other; teachers' being observed by the same subject professionals; having a warm, truthful, favorable and effective communication atmosphere during the implementation and rather away from rivalry and conflicts; observing teachers' being honest, truthful and objective; being applied by right teachers who are open for improvement and professional development; having support from school management.

(3) Peer observation was found by some of the participants to be a model that will remain unsuccessful because of not having enough number of teachers from each subject; not having enough time; teachers' being refrained from labeling as a "ineligible teacher" as their personal insufficiency in the class would be observed and noticed; teachers' not introducing their real teaching performance; having negative organizational culture; political and professional rivalries at schools; lack of confidence and trust among teachers.

\section{Suggestions}

When the quantitative and qualitative findings and results of the study were reviewed together, the following points can be suggested.

(1) The result of the study revealed that peer observation was mostly welcomed by school managers as an alternative teacher professional development model as well as a complementary supervision model. As a result, school managers should be informed about peer observation via CPD activities and this model can be added to school supervision system that will serve as an internal complementary supervision activity within Turkish school supervision system.

(2) Teachers and school managers should be trained and peers should be voluntarily chosen before implementing peer observation, more attention should be paid to teachers' being guided by other teachers from different schools; being positively reviewed via mutual understanding and respect as well as not offending each other; teachers' being observed by same subject professionals; having a warm, truthful, favorable and effective communication atmosphere during the implementation and away from rivalry and conflicts; observing teachers' being honest, truthful and objective; the method's being applied by teachers who are open for improvement and professional development; teachers' having support from school management during the peer observation process.

(3) In-service training courses related to the implementation of peer observation ought to be organized at larger scale along the country, and schools should be encouraged to implement this CPD model towards professional development of teachers.

\section{Acknowledgements}

I want to thank to the school managers, who are commissioned in İskenderun and Antakya districts of Hatay, for their precious participation in my study as well as peer observation and coaching conferences.

\section{References}

Aslanargun, E., \& Göksoy, S. (2013). Who Should Supervise Teachers? Usak University Journal Of Social Sciences, special issue, $98-121$.

Bell, M. (2002). Peer observation of teaching in Australia. Retrieved from http://www.heacademy.ac.uk/assets/York/documents/resources/database/id28PeerObservation_of_Teaching_in Australia.rtf

Bell, M. (2005). Peer observation partnerships in higher education. Milperra, NSW: HERDSA Inc.

Bell, A., \& Mladenovic, R. (2008). The benefits of peer observation of teaching for tutor development. Higher Education, 55(6), 735-752. https://doi.org/10.1007/s10734-007-9093-1

Bennett, S., \& Barp, D. (2008). Peer observation - A case for doing it online. Teaching in Higher Education, 13(5), 559-570. https://doi.org/10.1080/13562510802334871

Blanco, M.A. (2007). Training Medical Faculty Members to Review Peers' Teaching through Peer Observation. Doctoral Dissertation, Harvard University, Boston, Massachusetts, USA. 
British Council (2010). Peer observation. Retrieved 2nd February, 2010 from http://www.teachingenglish.org.uk/transform/teachers/teacher-development-tools/peerobservation/how-give-rec eive-feedback

Bourne-Hayes, C. Y. (2010). Comparing Novice and Experienced Teachers on Attitudes about Peer Observation as Professional Development. Doctoral Dissertation, Walden University, Minneapolis, USA.

Bowers, D. L. (1999). Teachers' use of peer observation and feedback as a means of professional development. Doctoral Dissertation, University of Southern California, USA, UMI: 9933793.

Bozak, A. (2014). Defining the Views of Teachers Towards the Practicability and Effectiveness of Peer Observation, Doctoral Dissertation, İnönü University, Malatya, Turkey.

Bozak, A. (2017). The opinions of the educational supervisors on legal arrangements about supervision system and their own occupation, Mustafa Kemal University Journal of Graduate School of Social Sciences, 14(38), 90-110.

Buluç, B. (1997). Türk eğitim sisteminde teftiş ve denetim alt sisteminin gelişim süreci. Bilgi Çă̆ında Ĕgitim Dergisi, 4, 27-30

Byrne B. (1983). Trainee uses of reciprocal peer supervision and of faculty supervision in psychotherapy training. Doctoral Dissertation, Temple University, Philadelphia, USA.

Clark, Carolyn A. (2017), Professional Growth: Informal Peer Observation. All Theses and Dissertations. 116. Retrieved from http://dune.une.edu/theses/116

Cosh, J. (1999). Peer observation: A reflective model. ELT Journal, 53(1), 22-27. https://doi.org/10.1093/elt/53.1.22

Crabtree, J. L., Scott, P. J., \& Kuo, F. (2016). Peer Observation and Evaluation Tool (POET): A Formative Peer Review Supporting Scholarly Teaching, The Open Journal of Occupational Therapy, 4(3), Article 9. https://doi.org/10.15453/2168-6408.1273

Cribbs, R. G. (2009). The effect of peer coaching on the practice of school psychologists. Doctoral Dissertation, University of West Georgia, Carrollton, Georgia, USA, UMI: 3383964.

Creswell, J. W., \& Garrett, A. L. (2008). The "movement" of mixed methods research and the role of educators. South African Journal of Education, 28(3), 321-333.

Creswell, J. W., \& Plano Clark, V. L. (2014). Karma yöntem araştırmalart: Tasarımı ve yürütülmesi. (Translation, Edited by Dede, Y. \& Demir, S. B.) Ankara, Turkey: Anı Publication.

Daymon, C., \& Holloway, I. (2003). Qualitative Research Methods in Public Relations and Marketing Communications. London: Rout ledge.

Doyle, M. J. (2012) Using Peer-to-Peer Observation to Improve Teacher Collaboration. Doctoral Dissertation, Capella University, Minneapolis, USA, UMI: 3544518.

Ergen, H., \& Eşiyok, İ. (2017). Teacher Opinions On School Principals' Instructional Supervision Performances, Journal of Contemporary Administrative Science, 3(1), 1-18.

Gündüz, Y. (2017). A Study on Fulfillment Levels of Supervisory Duties of School Principals In Primary Schools, Kastamonu Education Journal, 25(5), 1681-1694.

Hanna, H. J. (1988). A case study of instructional improvement through peer observation in a suburban high school. Doctoral Dissertation, Portland State University. (UMI Number: 8813113).

Hammersley-Fletcher, L., \& Orsmond, P. (2005). Reflecting on reflective practices within peer observation. Studies in Higher Education, 30(2), 213-224. https://doi.org/10.1080/03075070500043358

Hirsch, L. J. (2011). Utilizing Peer Observation as a Professional Development Tool to Learn in Context, Doctoral Dissertation, Northeastern University, Boston, Massachusetts, USA, UMI: 3494486.

Hornby, M. K. (2008). Peer coaching for new high school teachers. Graduate thesis, Royal Roads University, Victoria, Canada.

Karasar, N. (2005). Bilimsel Araştırma Yöntemi. Ankara: Nobel Publications Inc.

Joyce, B., \& Showers, B. (2002). Student achievement through staff development. Alexandria, VA: ASCD.

Rhodes, C., \& Beneicke, S. (2002). Coaching, Mentoring and Peer-networking: Challenges for the Management of 
Teacher Professional Development in Schools. Journal of In-Service Education, 28(2), 297-309. https://doi.org/10.1080/13674580200200208

Martin, G. A., \& Double, J. M. (1998). Developing higher education teaching skills through peer observation and collaborative reflection. Innovations in Education and Teaching International, 35(2), 161-170.

Morton, C. A. (2004). The relationship among planning activities, peer coaching skills and improved instructional effectiveness in preservice special education teachers, Doctoral Dissertation, University of Texas A \& M, UMI: 3132112.

Nelson, T. R. (2000). Analysis of a peer observation program for graduate teaching assistants to enhance instructional development, Doctoral Dissertation, Illinois University, Urbana, Illinois, USA. UMI: 9971147.

Özmen, F., \& Batmaz, C. (2006), İlköğretim Okul Müdürlerinin Öğretmen Denetimindeki Etkililikleri -Hizmet Yılı ve Görev Türü Değişkenine Göre Öğretmen Görüşleri, Social Sciences Research Journal, 2, 102-120.

Peel, D. (2005). Peer Observation as a Transformatory. Teaching in Higher Education, 10(4), 489-504. https://doi.org/10.1080/13562510500239125

Potter D. H. (1991). Peer Observation and Reflection: A Strategy for Collegial Interaction among Teachers. Doctoral Dissertation, Ohio State University, Ohio, USA.

Punch K. F. (2005). Introduction to Social Research-Quantitative \& Qualitative Approaches. London: Sage Publications Inc.

Rouser, S. S. (2009). Behind Closed Doors: A Case Study of the Impact of Peer Visits to Combat Isolation and Develop Reflective Practice in High School Teachers, Doctoral Dissertation, Capella University, Minneapolis, USA, UMI: 3344523.

Salvador J. (2012). Observation in a school without walls: Peer observation of teaching in a $2 n d-12^{\mathrm{TM}}$ grade independent school, Doctoral Dissertation, Pennsylvania University, USA, UMI: 3530055

Shenton, A. (2004). Strategies for ensuring trustworthiness in qualitative research projects. Education for Information, 22, 63-75. https://doi.org/10.3233/EFI-2004-22201

Shook, T. K. (2011). A qualitative examination of factors that contribute to transfer of learning by teachers who attended peer coach training, Doctoral Dissertation, Walden University, Minneapolis, USA.

Shortland, S. (2004). Peer observation: A tool for staff development or compliance? Journal of Further and Higher Education, 28(2), 219-228. https://doi.org/10.1080/0309877042000206778

Siddiqui, Z. S., Jonas-Dwyer \& Carr, S. E. (2007). Twelve tips for peer observation of teaching. Medical Teacher, 29(4), 297-300. https://doi.org/10.1080/01421590701291451

Su, K. (1974). Türk Ĕgitiminde Teftişin Yeri ve Önemi, Milli Eğitim Basımevi, İstanbul.

Sullivan, S., \& Glanz, J. (2000). Alternative approaches to supervision: Cases from the field. Journal of Curriculum and Supervision, 15(3), 212-235.

Straughter, B. (2001). The effects of peer observation on self-governance among elementary school teachers. Doctoral Dissertation, University of Johnson and Wales. (UMI: 3042729).

Tonbul Y., \& Baysülen E. (2017). An Evaluation of the Course Inspection Regulation According to the Views of Supervisors, Teachers and Principals. Elementary Education Online, 16(1), 299-311. https://doi.org/10.17051/io.2017.24494

Usta, M. E. (2018). An analysis of 1926 inspection legislation document, named: "Law about inspectors of education ministry and their authorization". Education Research and Review, 13(1), 32-50. https://doi.org/10.5897/ERR2017.3404

Uzuner, Y. (2005). Baş Makale: Özel Eğitimden Örneklerle Eylem Araştırmaları. Ankara Üniversitesi Eğitim Bilimleri Fakültesi Özel Eğitim Dergisi, No:6.

Walker R., \& Forbes D. (2017). Cross-institutional peer observation by online tutors: Sharing practice 'outside the family', Innovations in Education and Teaching International, June, 1-9.

Yıldırım \& Şimşek. (2006). Sosyal Bilimlerde Nitel Araştırma Yöntemleri. Ankara, Seçkin Publication.

Yıldız, B., Akbaşl1, S., \& Üredi, L. (2015). Kurum müdürlerinin yaptı̆̆ rehberlik ve denetim uygulamalarına ilişkin ögretmen görüsslerinin değerlendirilmesi. VII. International Congress of Educational Supervision, Dokuz Eylül 
University, İzmir.

Younghans, B. C. (2010). The superintendent's role in developing peer coaching, Indiana State University, USA, UMI: 3404470 . 